\title{
Teacher and student preferences of native and nonnative foreign language teachers
}

\author{
DANIEL MADRID \\ University of Granada \\ Mª Luisa Pérez CAÑado \\ University of Jaén
}

Received 31 March, 2004 / Version accepted 30 May, 2004

\begin{abstract}
The present paper focuses on the much debated issue of native and nonnative speakers as teachers of English. After offering a brief literature review of the research which has been conducted on the differences between native and nonnative teachers, it reports on the design and outcomes of a study carried out to obtain a deeper insight into student and teacher perceptions of the influence of native and nonnative teachers on the English language classroom. The results are enlightening, as both groups comprised in the sample find relevant differences between the pedagogical behaviour of native and nonnative teachers, with the students' preferences for native teachers increasing with academic level, and with the teachers valuing their presence from the Primary Education stage.

Key words: native-nonnative; differences; student and teacher perceptions; qualitative and quantitative data; questionnaire.

Resumen: Este trabajo se centra en el tema, tan debatido, de las diferencias entre los profesores de inglés nativos y no nativos. Después de hacer una revisión bibliográfica sobre los trabajos de investigación que se han realizado sobre el tema, presentamos un estudio que refleja la percepción de profesores y alumnos sobre el tema. Los resultados son bastante esclarecedores, ya que los grupos que componen la muestra muestran diferencias significativas entre el comportamiento didáctico del profesorado nativo y no nativo. Se observa también cómo las preferencias de los alumnos por el profesorado nativo aumenta a medida que suben de nivel académico y cómo el profesorado de Primaria y Universidad muestra una clara preferencia por el profesorado nativo en contraste con otros niveles académicos donde se considera menos prioritario.

Palabras clave: profesores nativos y no nativos; diferencias, percepciones de profesores y alumnos, datos cuantitativos y cualitativos.
\end{abstract}

\section{INTRODUCTION}

The place of nonnative speakers as teachers of English has been a controversial issue from the moment this language began to be taught internationally. Indeed, the native English speaking teacher (NEST) vs. non-native English speaking teacher (NNEST) question has generated an argument, polemic, or controversy - as it has been variously termed - which is growing in significance as the importance of learning languages in general, and English in 
particular, is increasingly acknowledged. The fact that the native-nonnative teacher issue has become a noteworthy topic of discussion is not surprising, given our profession's current championing of multiculturalism, multilingualism, and diversity and the recent interest in attaining bilingualism as a feasible objective for the near future in our country.

There have been attempts to define both terms, the differences between both options have been amply discussed, and arguments in favour or against each one have been tossed back and forth (Paikeday, 1985; Coppieters, 1987; Medgyes, 1992; Widdowson, 1993; Nayar, 1994; Liu, 1999). Some have put considerable effort into bringing more visibility to nonnative teachers of English and into giving them a voice in the profession, considering that their strengths are still somewhat unknown and their potential and contribution to the ELT field, underestimated. Thus, for example, research has been carried out to destroy the so-called native speaker fallacy and caucuses such as the NNEST Caucus in TESOL have been created (Braine, 1999; Maum, 2002). Others have concentrated on maximising the strengths of native and nonnative teachers through mutual sharing of linguistic, cultural, and educational insights within a model of joint collaboration (Matsuda, 1999; Matsuda and Matsuda, 2001). In this sense, what Matsuda (1999: 2) terms a "deficit model of teacher development", which views the native-nonnative dichotomy as discrete (NS or NNS), competitive (NS vs. NNS), or subtractive (strengths minus weaknesses), would be substituted by a "collaborative model of teacher qualification", which would involve integrative (Ns and NNS), cooperative (mutual sharing), and additive (NS strengths plus NNS strengths) elements.

Whatever the view adopted on the topic, it remains incontrovertible that the nativenonnative issue still arouses tremendous interest in the field of ELT. And, although numerous studies have been conducted into the matter, few have focused on the perceptions of teachers and students themselves (Moussu, 2000). This is precisely the aim of the present investigation: to explore teacher and student perceptions of the effectiveness of native and nonnative teachers of English in our immediate Andalusian context. To this end, we begin by offering a succinct overview of the research which has been carried out on the differences between native and nonnative teachers; on the distinctive traits of their pedagogical behaviour; and on the thoughts, beliefs, and perceptions nonnative teachers have of themselves, their attitudes, and their teaching performance. We then go on to report on the design and results of our study. Working with a sample of 459 students and 35 teachers from all educational levels (from Primary Education to University), and employing a questionnaire with both qualitative aspects - appraised through open questions - and quantitative data - gathered by means of closed ones - , the investigation reaches enlightening conclusions as regards both student and teacher perceptions of the influence of native and nonnative teachers on the English language classroom.

\section{Studies ON THE DIFFERENCES BETWEen NATIVE AND NONNATIVE TEACHERS}

Several studies have focused on the distinctive traits and peculiarities of the thoughts and performance of the nonnative L2/FL English teacher (cf. Barrios, 2002:47-48).

Horwitz (1992, 1993, in Horwitz, 1996) investigates the anxiety experienced by nonnative foreign language teachers - including a group of teacher trainees - and how it can influence the teaching/learning process. These teachers provided information on their feelings regarding language learning anxiety and on their preferred didactic strategies. The majority of the subjects exhibited considerable levels of language learning anxiety. Another relevant finding 
of these studies involved establishing a relationship between anxiety and the components of effective FL learning. The subjects in the investigation were asked to give their opinion of a set of classroom activities, such as role-plays, pattern drill practice, or grammatical expalnations in English and in the mother tongue, as well as to esteem the likelihood of their employment in class where the syllabus allowed it. Positive assessment of an activity, but unlikelihood of its implementation, was considered a sign of anxiety.

Those subjects who displayed a high level of anxiety saw more innovative and intensive activities involving FL use as less likely to be implemented, even if they had valued such activities just as positively as less anxious subjects. As regards teaching approaches, the most anxious subjects considered improbable the use of Total Physical Response activity types, as well as debates in the FL and role-plays, all of which involve a greater use and mastery of the FL on the teacher's part. With respect to teacher trainees, those exhibiting higher levels of anxiety stated that, as teachers, they would plan activities involving a more restricted use of the FL, much more so than stated by their more self-confident counterparts (Barrios, 2002: 47).

Brutt-Griffler and Samimy (1999) analyse the anxieties, experiences, and representations manifested by nonnative English teachers and the process of reconstruction of their collective and individual identities through their participation in a teacher training TESOL programme inspired in critical pedagogy and destined to empower nonnative teachers to make choices in the professional realm.

The awareness and experience of being a nonnative English teacher, the gradual acknowledgement of the multidimensional and plural nature of the ESL/EFL teaching professional and of his/her contribution to the language teaching realm, and the critical analysis of his/her experiences and professional context were the most relevant topics identified in the data analysed (Barrios, 2002: 48).

Reves and Medgyes (1994) have researched the perceptions which nonnative English teachers have of themselves, their attitudes, and teaching behaviour, analyzing these aspects through a questionnaire administered to English teachers in ten different countries $(91.7 \%$ of the sample being made up of nonnative teachers of English).

The results reveal that the teachers who answered the questionnaire observed differences between native and nonnative teachers of English, both in their use of the L2/FL and in their approach to language teaching, differences they ascribed primarily to their diverse level of mastery of the language. Similarly, the nonnative teachers' limited knowledge of English caused them to favour the isolated practice of linguistic elements or in poor linguistic contexts. However, on the other hand, these nonnative teachers believed they had a greater awareness of the mechanisms involved in language acquisition and use, as well as a superior capacity to assess the students' potential and to anticipate their possible areas of difficulty (Barrios, 2002: 48).

Numerous have been the studies which have sought to destroy the myth of the native teacher and his/her alleged superiority with respect to the nonnative one. Thus, for example, Kachru (1985) writes a book under the eye-catching title of The Native Speaker is Dead! and Davies (1991: 157) claims: "The native speaker is a fine myth: we need it as a model, a goal, almost an inspiration. But it is useless as a measure". Nonetheless, the native - nonnative dichotomy is still vastly employed, with a myriad of studies evincing the differences between them and outlining the pros and cons, the strengths and weaknesses of each option. 
For instance, Árva and Medgyes (2000) have investigated the diverse traits of native and nonnative teachers and of their pedagogical behaviour. Medgyes (1994) has highlighted the following differences between them:

- Native and nonnative teachers differ in level of L2 competence.

- They also tend to differ in terms of teaching behaviours.

- Such differences in teaching behaviour derive from their differences in linguistic competence.

- Both can be equally qualified teachers.

Medgyes (1994) confirms the previous hypotheses taking as a basis the answers provided by 325 participating teachers in 11 different countries. In a subsequent study, Árva and Medgyes (2000) set out to answer the following questions:

- Which differences in teaching behaviour can be detected between native and nonnative teachers?

- To what extent can these differences be attributed to their differing levels of linguistic competence?

- Are there any other causes which can account for the differences observed?

- Which differences exist between the opinions of natives and nonnatives?

The study was carried out in Hungary, with five native speakers of English from England, and five nonnative speakers of English from Hungary, all secondary school teachers. The latter were interviewed on how they perceived their teaching skills and ten video recordings were made of their performance in class.

\section{L2 competence of native and nonnative teachers}

The main advantage of native teachers is evidently to be found in their superior linguistic and communicative competence of the L2 (English), since it is their mother tongue and they can thus use it with greater spontaneity and naturalness in a considerable variety of situations. On the other hand, nonnative teachers usually display a poorer competence, acquired through study and effort, which disallows spontaneity. In addition, they normally experienced problems with pronunciation, colloquial expressions (particularly slang), and certain types of vocabulary (Árva and Medgyes, 2000: 261). Their linguistic competence was also slightly outdated and very much influenced by textbook language, as they used the latter to provide linguistic models to their students.

\section{Grammatical knowledge}

One of the most outstanding pitfalls of native teachers identified was their poor knowledge of grammar. Some of these teachers would state: "This is wrong and this is the correct way you should say it, I know, but I can't explain why it's wrong or right" (Árva and Medgyes, 2000: 261). Quite on the contrary, knowledge of English grammar was often a source of pride for nonnative teachers, since they had studied it in depth and were capable of providing scientific explanations for the constructions and use of the English language. This aspect was 
in fact taken into account when assigning teaching functions and responsibilities: native teachers would be in charge of conversation classes, whilst nonnative ones would be responsible for the scientific study of the language and its literature.

\section{L1 competence}

Native teachers' lack of knowledge of Hungarian, the students' mother tongue, influenced the lack of empathy between teachers and students, especially at elementary and intermediate levels. One teacher lamented this circumstance: "I can't explain fully, especially with beginners, and it can be frustrating". Another one claimed: "It must be wonderful to be Hungarian and, if students have a problem, to explain it in Hungarian" (Árva and Medgyes, 2000: 261). Obviously, this problem did not arise with the nonnative (Hungarian) teachers.

Other aspects of profesional performance

Young native British teachers were very casual with the Hungarian students, and were thus sometimes not considered true teachers, but rather, assistants who helped them practice English, as the following comment evinces: "The students don't view him as a teacher, but as a young chap messing about in sneakers". Such teachers normally did not assign homework or insist on the need of previous preparation of classroom exercises. They also tended not to use textbooks, but rather, numerous handouts they distributed for their lessons. Nonnative Hungarian teachers, on the other hand, behaved more formally, gave more homework, and were stricter with those who failed to do it or who did not use their textbooks in class.

The results of the Árva and Medgyes (2000) study also revealed the following differences:

- Native teachers obviously spoke English better than their nonnative counterparts and used it as a natural means of communication in class.

- Nonnative teachers had a far superior metacognitive knowledge of English grammar.

- Nonnatives followed textbooks faithfully, whereas natives employed a vast gamut of activities (newspaper clippings, photocopies, posters, realia) and seldom stuck to what the coursebook dictated.

- Natives were much more lenient with student mistakes and casual in giving their lessons.

- Native teachers caused the students to be more highly motivated due to the fact that they were forced to use the L2 as a means of communication since they did not speak Hungarian. In this sense, they acted as true facilitators of the communication process.

- Nonnatives prepared their lessons meticulously and more professionally.

- Natives provided the students with more cultural insights and were thus used by the learners as rich sources of cultural information.

Although certain authors have vouched for the superiority of trained nonnative teachers over unprepared native ones (in van Essen, 1994), the assets displayed by the native British speakers, even with scarce didactic preparation, studied by Árva and Medgyes (2000), evince that one cannot be readily inclined towards one or another type of teacher, as both have assets and drawbacks to offer. 


\section{RESEARCH OBJECTIVE}

The present study aims to provide an answer to the following question, bearing in mind EFL student and teacher perceptions:

With whom do teachers and students believe one learns more: with native or with nonnative teachers?

\section{INSTRUMENTS FOR VARIABLE CONTROL}

To provide the previous question with an answer and to control the variables involved in the objective of our study, we have made use of a questionnaire. We have asked the teachers and students comprised in our sample the following:

a) Qualitative data

Briefly state your opinion on the incidence of the following aspects on the students learning process. Continue on the back side of the page if necessary.

Do you believe that having a native teacher influences the outcomes of the learning process? Why? Does a nonnative teacher who constantly uses the FL fulfil the same function as a native one? Which of the two do you prefer?

\section{b) Quantitative data}

Give your opinion on the following statements using this scale:

4 = always $\quad 3=$ almost always $\quad 2$ = sometimes $\quad 1=$ seldom $\quad 0=$ never

(....) 1.Native teachers are preferable to nonnative teachers and you learn more with them.

(....) 2.Nonnative teachers are preferable to native teachers and you learn more with them.

The first part of the questionnaire comprises qualitative aspects and is made up of open questions which reflect teacher and student perceptions, opinons, and beliefs as regards native and nonnative teachers. The closed questions encompassed in section b) gather quantitative and objective data about the sample.

As is widely acknowledged, the questionnaire or survey is perhaps the most vastly employed instrument in educational research (cf. Cohen and Manion, 1989; Fox, 1981). It is especially useful to explore the conditions in which the teaching/learning process takes place from the point of view of teachers and students. It equally provides information about certain beliefs and opinions which are at the core of teacher and student thoughts. Taking these opinions as a point of departure, certain norms and patterns can be identified which are 
systematically repeated in connection to certain classroom contexts. Finally, the relations and correlations which exist between the data obtained can be established.

\section{SAMPLE}

We have not been able to select the sample randomly, but have rather employed the data obtained from those institutions who acceded to the administration of the questionnaires. The subjects to whom the questionnaires have been applied are as follows:

\section{STUDENTS}

\begin{tabular}{|c|c|c|c|c|c|}
\hline \multirow[t]{2}{*}{ School } & \multirow[t]{2}{*}{ Town } & \multirow[t]{2}{*}{ Grade } & \multicolumn{2}{|c|}{ Students } & \multirow[t]{2}{*}{ TOTAL } \\
\hline & & & Boys & Girls & \\
\hline I.E.S. "Pablo Ruiz Picaso" & Chiclana (Cádiz) & $\begin{array}{l}\text { 2nd } \\
\text { CSE* }\end{array}$ & 6 & 13 & 19 \\
\hline Vocational Training & Osuna (Sevilla) & 3rd CSE & 5 & 9 & 14 \\
\hline I.B. "Incla Garcilaso" & Montilla (Córdoba) & 3rd CSE & 21 & 12 & 33 \\
\hline I.B. "Padre Suárez" & Granada & 3rd CSE & 13 & 15 & 28 \\
\hline San Juan Bosco & Granada & 2nd CSE & 8 & 9 & 17 \\
\hline San José & Granada & 5th P. E. & 13 & 9 & 22 \\
\hline I. B. "Inca Garcilaso" & Montilla (Córdoba) & 2nd CSE & 20 & 12 & 32 \\
\hline Victoria Eugenia & Granada & 1st CSE & 8 & 21 & 29 \\
\hline I.E.S. "Camilo José Cela" & \begin{tabular}{|l|} 
Granada \\
\end{tabular} & 3rd CSE & 12 & 13 & 25 \\
\hline C.P. "Luisa Marillach" & Granada & 6th P.E. & 7 & 5 & 12 \\
\hline Amor de Dios & Granada & 1st CSE & 9 & 10 & 19 \\
\hline Amor de Dios & Granada & 2nd Bach & 15 & 14 & 29 \\
\hline " & " & 4th CSE & 13 & 15 & 28 \\
\hline Dulce Nombre de María & Granada & 6th P.E. & 19 & 6 & 25 \\
\hline " $\quad$ " & $"$ & 2nd CSE & 28 & 3 & 31 \\
\hline " $\quad "$ & " & 4th CSE & 17 & 4 & 21 \\
\hline I.B: "Francisco Javier de Burgos" & Motril (Granada) & 4th CSE & 13 & 17 & 30 \\
\hline Faculty of Education (University of Granada) & Granada & $\begin{array}{l}\text { 2nd and } \\
\text { 3rd years }\end{array}$ & 6 & 39 & 45 \\
\hline & & TOTAL & 233 & 226 & 459 \\
\hline
\end{tabular}

\section{TEACHERS}

Summary of cases within the sample of teachers:

\begin{tabular}{|l|c|l|}
\hline Total number of teachers & $\mathbf{3 5}$ & $100 \%$ \\
\hline Types of institutions where they work & $\mathrm{N}$ & $\%$ \\
\hline In marginal area & 2 & 2,9 \\
\hline In public rural & 5 & 14,3 \\
\hline In public urban & 20 & 57,1 \\
\hline In private & 3 & 8,6 \\
\hline At university & 6 & 17,1 \\
\hline
\end{tabular}




\begin{tabular}{|c|c|c|}
\hline \multicolumn{3}{|l|}{ Academic levels } \\
\hline 3rd Cycle of Primary & 9 & 25,7 \\
\hline 1st Cycle of CSE & 7 & 20 \\
\hline 2nd Cycle of CSE & 8 & 22,9 \\
\hline Bachillerato & 5 & 14,3 \\
\hline University & 6 & 17,1 \\
\hline \multicolumn{3}{|l|}{ Gender } \\
\hline Male teachers & 17 & 48,6 \\
\hline Female teachers & 18 & 51,4 \\
\hline \multicolumn{3}{|l|}{ Age } \\
\hline From 20 to 30 & 7 & 20 \\
\hline From 31 to 40 & 15 & 42,9 \\
\hline From 41 to 50 & 12 & 34,3 \\
\hline Over 50 & 1 & 2,9 \\
\hline \multicolumn{3}{|l|}{ Teaching level } \\
\hline Primary & 9 & 25,7 \\
\hline Secondary & 20 & 57,1 \\
\hline University & 6 & 17,1 \\
\hline \multicolumn{3}{|l|}{ Ideology and political militance } \\
\hline Does not belong to a political party & 35 & 100 \\
\hline \multicolumn{3}{|l|}{ Religious beliefs } \\
\hline Non-practicing Catholic & 27 & 77,1 \\
\hline Practicing Catholic & 8 & 22,9 \\
\hline
\end{tabular}

\section{RESULtS}

\subsection{Student perceptions of the influence of native and nonnative teachers on the English language classroom}

Both students and teachers have found relevant differences between the pedagogical behaviour of native and nonnative teachers. Some of these differences have been formulated in the following terms:

\section{QUALITATIVE DATA}

\section{PRIMARY Education students}

- The native teacher has a greater capacity, has practised since childhood and has a better pronunciation, has a better expression and provides better explanations, and knows more vocabulary and spelling rules because English is his/her language. 
- Although (s)he may be native, (s)he may not express him/herself well and may know less than a nonnative.

- You don't achieve better results with a native because the accent is difficult and different.

- The Spanish teacher explains grammar in Spanish and you understand it better; then, we do the exercises in English and that's it (cf. in this sense Árva and Medgyes, 2000).

- If the teacher is native and (s)he does not know how to explain things well, you don't learn.

\section{Perceptions of CSE students}

- The native teacher is not taken seriously (cf. Árva and Medgyes, 2000).

- The native teacher has a higher level and achieves better results.

- The native teacher knows the language more and has a better expression. (cf. Árva and Medgyes, 2000).

- It's preferable for the teacher to be Spanish, because we don't understand a native speaker.

- The nonnative teacher is better, because (s)he speaks more in Spanish than in English and so we learn more. If (s)he is native, we don't understand anything.

- I prefer natives.

- You always learn much more if the teacher is native. You can't teach an English class in Spanish! I would vote in favour of speaking only English in class from the third year of CSE onwards.

Perceptions of BACHILLERATO students

- Natives are better teachers because they master the language they teach, have a profound knowledge of it, have a greater self-confidence, and all this exerts an influence on the results.

- The main issue is not being native or nonnative, but knowing how to teach the language, how to explain it, and how to make the students like it.

- Of course it's influential, since I'm in favour of teaching half the class time in the L2, and a native masters the language being taught and can do it better.

- I've never experienced the difference, but $I$ think that a native is preferable to a nonnative.

\section{QUANTITATIVE DATA}

The opinion voiced by the groups who make up the sample on the importance of native and nonnative teachers in the teaching/learning process of English as a Foreign Languge is reflected in the table below: 


\begin{tabular}{|c|c|c|c|c|c|c|c|c|c|c|c|c|}
\hline \multirow{2}{*}{$\begin{array}{l}\text { (STUDENT } \\
\text { OPINIONS) }\end{array}$} & \multicolumn{2}{|c|}{ Primary } & \multicolumn{2}{|c|}{$\operatorname{CSE}^{*}(I)$} & \multicolumn{2}{|c|}{ CSE (2) } & \multicolumn{2}{|c|}{ Bachillerato } & \multicolumn{2}{|c|}{ University } & \multicolumn{2}{|c|}{ ANOVA } \\
\hline & M & $S D$ & $M$ & $S D$ & $M$ & $S D$ & M & $S D$ & $\mathrm{M}$ & SD & $F$ & Sig. \\
\hline $\begin{array}{l}\text { V1. Preference for } \\
\text { native teachers }\end{array}$ & 1.57 & .87 & 1.62 & .79 & 2.66 & .56 & 2.20 & .14 & 2.26 & .49 & 2.31 & .08 \\
\hline $\begin{array}{l}\text { V2. Preference for } \\
\text { NONnative } \\
\text { teachers }\end{array}$ & 2.26 & .81 & 1.83 & .66 & 1.63 & .15 & 1.85 & .21 & 1.70 & .43 & 1.17 & .34 \\
\hline
\end{tabular}

$\operatorname{CSE}(1)=$ First Stage of the Compulsary Second Education

The students' opinions are quite homogeneous, although it can be observed that, as their academic level increases and they pass on to the higher grades, their preference for the native teacher also increases. Thus, for example, Primary students' preferences for native teachers have obtained a mean score of 1.57 , while, at university, it has increased to 2.26 . Nevertheless, it is important to point out that the analysis of variance carried out reveals that these differences are not statistically significant.

\subsection{Teacher perceptions of the influence of native and nonnative teachers on the English language classroom}

\section{QUALITATIVE DATA}

\section{PRIMARY Education teachers}

- It's like night and day, as it is very important to give the lesson in English, and the native can do so in a more natural way.

- Theoretically, the native teacher is faced with an easier task: working on phonetics, etc., but (s)he won't be more effective if (s)he doesn't know how to teach it.

- Being native exerts no influence whatsoever. You can teach the language just the same being nonnative. Wherever feasible, it is best to use the L2.

- The native teacher obviously has a greater mastery of the FL, but I think the nonnative can fulfil the same function provided (s)he is well prepared and uses the L2.

- I think the native teacher can obtain better resuts, because oral communication is the most important aspect and the native can develop it better (cf. Árva and Medgyes, 2000).

Opinions of CSE and BACHILLERATO teachers

- It depends on the educational level. At initial levels, knowing the students' mother tongue might be preferable.

- I leave the myth of the native teacher for academies: a teacher should know how to use the L2 without becoming obssessed, resorting to the L1 where necessary and avoiding inferiority complexes.

- The quality of the teaching/learning process is the same if the nonnative teacher knows and speaks the L2 perfectly.

- I think the native teacher achieves better results in oral terms. In writing, there are no differences.

- A pedagogically trained native teacher would be hard to beat, as (s)he will always 
offer high quality input. However, at the same time, (s)he may not be familiar with the language learner's processes, since (s)he has never had that experience as (s)he learnt in a natural way (cf. Barrios, 2002).

- A native teacher is preferable to a nonnative one, since the latter tends to use the L1 in class and his/her pronunciation is never the same.

- The most influential factor is the active use of the L2 in class, not the teacher's origin.

Opinions of UNIVERSITY teachers on the native/nonnative variable

- If (s)he acts as a linguistic model, this is bound to incide on the students' oral competence, especially on their pronunciation.

- It doesn't necessarily have to exert an influence. I personally prefer a nonnative teacher, since (s)he is familiar with the mistakes and difficulties the students are going to encounter, while the native teacher is not as sensitized to the linguistic needs of the learners and does not know how to solve his/her students' problems with the same ease as his/her nonnnative counterpart.

- A nonnative teacher is to be preferred, provided (s)he has receives adequate training.

- A native teacher may be more convenient when it comes to developing oral expression, but on the remaining aspects, it makes no difference.

- If (s)he has experience in language teaching at different levels and has received proper philological and didactic training, a native teacher is preferable at intermediate and advanced levels; otherwise, it makes no difference.

\section{QUANTITATIVE DATA}

The absolute values of the means seem to indicate that, whereas students' interest in native teachers increases as they advance academically, teachers value their presence from the Primary Education stage, as can be observed in the following table:

\begin{tabular}{|c|c|c|c|c|c|c|c|c|c|c|}
\hline \multirow{2}{*}{$\begin{array}{l}\text { Variables related to the factors } \\
\text { "being nativel nonnative" } \\
\text { (TEACHER OPINION S) }\end{array}$} & \multicolumn{2}{|c|}{ Primary } & \multicolumn{2}{|c|}{ Secondary } & \multicolumn{2}{|c|}{ Bachillerato } & \multicolumn{2}{|c|}{ University } & \multicolumn{2}{|c|}{ ANOVA } \\
\hline & $\mathrm{M}$ & $S D$ & M & $S D$ & M & $S D$ & $\mathrm{M}$ & SD & $F$ & Sig. \\
\hline $\begin{array}{l}\text { V1. Preference for native } \\
\text { teachers according to EL } \\
\text { learning. }\end{array}$ & 2.22 & 1.09 & 1.93 & .46 & 2.00 & 1.00 & 2.33 & .82 & .34 & .84 \\
\hline $\begin{array}{l}\text { V2. Preference for NONnative } \\
\text { teachers according to EL } \\
\text { learning.. }\end{array}$ & 1.78 & .83 & 2.00 & .00 & 1.60 & 1.14 & 2.23 & .52 & 1.03 & .40 \\
\hline
\end{tabular}

Nonetheless, the analysis of variance between different cademic levels once again indicates that the previous differences are not statistically significant. 


\section{Conclusions}

Our aim in this study has been to answer the following question:

With whom do students and teachers believe one learns more: with native or nonnative teachers?

The results of the study portray that students do not evince a preference for native teachers, whom they value as much as nonnative ones. However, the teachers in the sample are slightly inclined towards native as opposed to nonnative teachers and acknowledge the advantages the former have in the language teaching/learning process. The reasons adduced by both teachers and students as regards this variable can be summarised as follows:

NATIVES
\begin{tabular}{ll}
\multicolumn{1}{c}{ NON-NATIVES } \\
- They teach the FL with greater & - They are better at explaining \\
esase. & grammar. \\
- They are difficult to understand in & - They are better understood when \\
the early grades. & they speak the FL. \\
- They are not taken seriously. & - They are preferred at lower levels. \\
- They are preferred to the nonnative & - They are sometimes to be preferred \\
teacher in the higher grades. & since they are more acquainted \\
- It is important to give the lesson in & with the FL learning processes as \\
English and the native teacher can & they have first-hand experience in \\
do so more easily. & learning and using the foreign \\
They can obtain better outcomes in & language. \\
oral communication. & - With proper training, they can be \\
& preferable to native teachers.
\end{tabular}

Nonetheless, as the students advance on to the higher grades, their preference for the native teacher also increases.

Despite the differences which can be gleaned from the teachers' and students' qualitative data, the quantitative study has not revealed any statistical significance between them.

\section{FurTher Research STUdies ON THE TOPIC}

This paper focuses on the perception that students and teachers have about native and non-native teachers, but it has not studied what other social agents think and demand. As the referees who have evaluated this work have pointed out, the paper does not refer to the impact of the market on preferences for native speaking teachers, yet state-supported international TESOL is operating alongside a private sector that is very influential, and which has responded to market-pressures for native speakers. Similarly the issue of parental and employer preferences is an important issue that has not been studied and could be covered by future studies. 
In the longer term, it would be also well worth looking at what happens with languages other than English. The pressure from NNS teachers is increased by bids for the EFL/ESOL market by countries that are not classed as native-speaking (eg. Denmark, Netherlands). Since non-European students often want English-medium teaching, non NS countries risk being excluded from the market in advanced students unless they can establish a role for NNS teachers. So establishing how NS and NNS teachers operate among, eg., French or German teachers in UK or Spain will give a useful base for comparative statements.

Future research papers can also study how do perceptions relate to expert versus less expert NNS's, to 'standard/RP' NS's versus 'non-standard', to older versus younger teachers, to those NNS's who have spent time in NS countries versus those who haven't - and so on.

\section{REFERECES}

Árva, V. and Medgyes, P. (2000). "Natives and non-natives teachers in the classroom”. System, 28 (3), pp. 355-372.

Barrios, M. E. (2002). El pensamiento y la actuación de futuros maestros de inglés durante su intervención didáctica en las prácticas de enseñanza. Doctoral Dissertation: Universidad de Granada: Departamento de Filología Inglesa.

Braine, G. (1999). "Nonnative English speakers in TESOL caucus formed", in TESOL Matters, 9, 1: $1-2$.

Brutt-griffler, J. and Samimy, K. K. (1999). "Revisiting the Colonial in the Postcolonial: Critical Praxis for Nonnative-English-Speaking Teachers in a TESOL Program”, TESOL Quarterly 33 (3), pp. 413-431.

Cohen, L. and Manion, L. (1989). Métodos de investigación educativa. Madrid: Muralla.

Coppieters, R. (1987). "Competence difference between native and near-native speakers", in Language, 63: $544-73$.

Davies, A. (1991). The Native Speaker in Applied Linguistics. Edinburgh: Edinburgh University Press.

Fox, D. (1981). El proceso de investigación en educación. Pamplona: Universidad de Navarra.

Horwitz, E. K. (1992). "Not for Learner's Only: The Language Anxiety of Nonnnative Teacher Trainees". Conference paper presented in the annual meeting of the International Association of Teachers of English to Speakers of Other Languages, Vancouver, Canadá.

Horwitz, E. K. (1993). "Foreign Language Anxiety and Preservice Language Teachers". Conference paper presented in the annual meeting of the American Council of Teachers of Foreign Languages. San Antonio, Texas.

Horwitz, E. K. (1996). "Even Teachers Get the Blues: Recognizing and Alleviating Language Teachers' Feelings of Foreign Language Anxiety", in Foreign Language Annals 29 (3), pp. 364-372.

Kachru, B. B. (1985). "Standars, codification and sociolingustic realism: the English language in the outer circle, in Quirk, R. and Widdowson, H. G. (eds.) (1985), pp. 10-30.

Liu, J. (1999). "From their own perspectives: The impact of non-native ESL professionals on their students", in G. Braine (ed.): Non-native Educators in English Language Teaching. Mahwah, NJ: Erlbaum, 159-176. 
Matsuda, A. and Matsuda, P. K. (2001). "Autonomy and collaboration in teacher education: Journal sharing among native and nonnative English-speaking teachers". CATESOL Journal, 13, 1: 109-121.

Matsuda, P. K. (1999). "Teacher development through native speaker-nonnative speaker collaboration", in TESOL Matters, 9, 5: 1-10.

Maum, R. (2002). "Nonnative-English-speaking teachers in the English teaching profession", in ERIC Digest. [On-line]. Available at: http://www.cal.org/ericcll/digest/0209maum.html.

Medgyes, P. (1992). “Native or non-native: Who's worth more?", in ELT Journal, 46, 4: 340-349.

Medgyes, P. (1994). The Non-Native Teacher. London: MacMillan Publishers.

Moussu, L. (2000). "Native versus nonnative speakers of English: Students' reactions". [On-line]. Available at http://www.moussu.net/courses/portfolio/540.pdf.

Nayar, P. B. (1994). "Whose English is it?", in TESL-EJ, 1, 1. [On-line]. Available at http: // www.kyoto-su.ac.jp/information/tesl-ej/ej01/f.1.html.

Paikeday, T. (1985). The Native Speaker Is Dead!. Ontario: Paikeday Publishing, Inc.

Reves, T. and Medgyes, P. (1994): "The Non-Native English Speaking EFL/ESL Teacher's SelfImage: An International Survey", SYSTEM 22 (3), pp. 353-367.

Widdowson, H. G. (1993). "The ownership of English", in TESOL Quarterly, 28: 377-389. 